\title{
Cultural Heritage Management as a Generator of Socio-Economic Development (The Case Study of Syria)
}

\author{
Mahmoud Abdulkader Alghafri ${ }^{1, *}$ Vasili Ivanovich Veklenko ${ }^{2}$, and \\ Mohannad Mohammad Ali ${ }^{3}$ \\ ${ }^{1}$ Department of Tourism Management, Faculty of Tourism, Damascus University, St. Al- Bramekah, \\ Damascus 0100, Syria - Institute of Economics and Management, Kursk State University, \\ St. Radishcheva, No. 33, Kursk 305000, Russia. \\ ${ }^{2}$ Department of Finance and Credit, Institute of Economics and Management, Kursk State University, \\ St. Radishcheva, No. 33, Kursk 305000, Russia. \\ ${ }^{3}$ Department of Tourism Management, Faculty of Tourism, Damascus University, St. Al- Bramekah, \\ Damascus 0100, Syria - School of Economics and Management, Far Eastern Federal University, \\ St. Sukhanova, No. 8, Vladivostok 690090, Russia.
}

\begin{abstract}
The purpose of the study was to determine the methods of successful management plan in cultural heritage sites. In addition to that, the research task was to clarification the nexus between cultural heritage and sustainable economic development in an operational and empirical manner. In the empirical part of the study, the main concern was finding out how to merge the cultural heritage sites in economic development projects for the local economy development. The methodology adopted for this study involved an innovative combination of economic and social assessment techniques. Economic assessment techniques applied included value analysis of cultural heritage sites. The study showed the culture heritage plays a significant role in the regeneration and development of local and regional areas. Contrary to expectations, the results indicated the great relationship between cultural heritage and socio-economic development to develop regional and local economy. Consistent to earlier research the study supported the hypothesis that using cultural heritage in local economic development projects. The results can be applied to cultural heritage sites and tourist destinations. Further study is required to investment of cultural heritage sites to achieve socio- economic development.
\end{abstract}

Keywords: Development economic value, heritage tourism, management plan, social value.

\section{Introduction}

Cultural heritage $(\mathrm{CH})$ of all kinds and forms is a source of pride for nations values and meanings are evidence of originality [1], and the expression of national identity as a link

*Corresponding author: $\underline{\text { alghafari.mahmoud@gmail.com }}$ 
between the past and the present [2]. It is one of the important resources of the tourism industry and the most important resource of society through the process of development, in which cultural heritage has become an integral part of any society with which it has an asset $[3,4]$. Therefore, many countries are seeking to maximize the return of cultural heritage in the process of social and economic development, as an important source of the tributaries of the national economy [5,6]. The international charters and agreements provides that the heritage is belong all the people, so the responsible of protection cultural heritage is collective responsibility consists of the human, society and government in local, regional and international levels [7]. The heritage is associated with society and each of society has their heritage and culture [8], the importance of the cultural heritage comes from the human and society memories so we should to conserve it $[9,11]$, in addition should to raise awareness of local community to protect and conserve the heritage in all his meanings and shapes $[12,13]$.

\subsection{Problem of the research}

The cultural heritage has become an integral part of any society, so there are more difficult to apply $\mathrm{CH}$ in the process of social and economic development projects.

\subsection{Research questions}

The research will be give solutions to solve the problems of the research through this questions: how can $\mathrm{CH}$ be included in social and economic development projects?; how to raise awareness of local community to protect and conserve the heritage in all his meanings and shapes?; what the Measures of undertaken by local government to encourage the investments in $\mathrm{CH}$ sites?

\subsection{Purpose of the study}

The purpose of the reseach was to determine the methods of successful management plan in $\mathrm{CH}$ sites in Syria. Moreover, this research task was to clarification the relation between $\mathrm{CH}$ and sustainable economic development in an operational and empirical manner.

\subsection{Research data}

This study consist of two levels of data. Primary data includes questionnaires and interviews. Whereas Secondary data deals with reviews and relevant inputs. Context relates single case study approach from empirical data concentrating on two Syrian famous cities Damascus and Aleppo. Local community and managers designed and administered two batches of these questionnaires.

\subsection{Research method}

Article is based upon the practical and quantitative analysis for inhabitants and managers. SPSS Version 25 was used for the finding. It includes the connection between heritage sectors with local economic development. It took around seventeen days in September 2018 to conduct the main survey. Yates sampling was the input for simple random sampling [14] that was taken into accounts for questionnaires survey named as Q1-local respondents. Where as, Q2 management personnel as based on purpose sampling. Cronbach's Alpha $(\alpha)$ was the frequently used tools for reliability. 0.70 can be said as sufficient although most of 
researchers thinks 0.60 as enough. It is used as the test of the internal consistency and reliability of a psychometric score for experiments. A generally established rule of thumb for expressing internal consistency using the Cronbach's Alpha is the following (Table 1).

Table 1. The variables which are used in the research

\begin{tabular}{|l|c|c|c|}
\hline \multicolumn{1}{|c|}{ Variables } & No. of items & $\begin{array}{c}\text { Local community } \\
\text { Cronbach's Alpha }\end{array}$ & Strength \\
\hline Stakeholders' attitude on the situation of CH sites & 12 & 1.095 & Excellent \\
\hline $\begin{array}{l}\text { Cultural tourism and its benefits for the conservation of } \\
\text { Syrian CH sites }\end{array}$ & 13 & 0.570 & Weak \\
\hline $\begin{array}{l}\text { The significance of preserving the unused values of the } \\
\text { CH in Syria }\end{array}$ & 6 & 0.670 & Moderate \\
\hline $\begin{array}{l}\text { The socio- economic management of the Syrian CH } \\
\text { sites }\end{array}$ & 8 & 0.260 & Weak \\
\hline $\begin{array}{l}\text { The involvement of local community in Syrian CH } \\
\text { sites management }\end{array}$ & 7 & 0.701 & Good \\
\hline
\end{tabular}

Spearman's Rho Correlation and the Pearson's Correlation are the main reason behind this statistics to investigate the significance of the relationship between two constraints. Symbol $\mathrm{r}$ is the correlation coefficient $(-1<\mathrm{r}>1)$. Perfect correlation indicates that variables is completely dependent on the other variable and decisions can be made very precisely, i.e. 0.1 to 0.29 or -0.1 to -0.29 means weak strength, 0.30 to 0.49 or -0.30 to -0.49 means moderate, 0.50 to 1.0 or -0.50 to -1.0 means strong.

\subsection{Research methodology}

After the literatures review on heritage, management and socio- economic development, we have chosen for a quantitative methodological instruments (the survey for local community) and qualitative methodological (the survey for managers). In the another hand, Consequently, it has used mixture of both methods. The distributed of surveys to local community in the center of the cities (Damascus and Aleppo, the total number 300 with about 291 responses for local community). The distributed of surveys to managers (tourism officer, academician, conservation officer and ngo activist), the total number 25 with about 19 responses.

\section{The basic theory of "cultural heritage management"}

Direct economic contribution to culture related activities for the sake of enriching cultural. Goods and services was represented by the heritage management and development projects triggering indirect economic impact $[15,16]$. Moreover, technical services providers, administrative and financial services, cultural tourism-related services, transports, goods and services are additional economic benefits [17-19]. Bernard [20] and Darko [21] have been using "Cultural heritage as a generator of the socio-economic development" theory.

\section{Research model}

This article analyzing the crossed points between cultural heritage and socio-economic development projects in Syria according to the models by UNESCO, ICOMOS. In addition to these models, more models were done by $[22,25]$. The above mentioned researchers are conducted in developing economy for countries which has the same conditions as Syrian's economy. 


\section{Research results and discussion}

Table 2 is based upon the responses from the questionnaires of interest group. When overall rates reaches $97 \%$ for inhabitants and $76 \%$ for managers it denotes maximum. Whereas, in Table 3, five point Likert's Scale were examined. The scales were inputted as 'agree' and 'disagree' for frequency analysis. The research for the maximum position in conservation management in cultural heritage sites (CHS) played a significant role and emphasized on improvement in local economic enrichment as mentioned in Table 3.

Table 2. The responses rates for questionnaires involving the stakeholders (local community and managers)

\begin{tabular}{|c|c|c|c|c|}
\hline No. & Stakeholder & $\begin{array}{c}\text { Number of a questionnaire } \\
\text { distributed }\end{array}$ & $\begin{array}{c}\text { Number of } \\
\text { responses }\end{array}$ & Percentage (\%) \\
\hline 1. & Local community & 300 & 291 & $97 \%$ \\
\hline \multicolumn{2}{|c|}{ Total } & 300 & 291 & 100.0 \\
\hline 2. & Managers & 25 & 19 & $76 \%$ \\
\hline \multicolumn{2}{|c|}{ Total } & 25 & 19 & 100.0 \\
\hline
\end{tabular}

Table 3. The socio- economic management of the Syrian cultural heritage sites (Total Mean 3.53)

\begin{tabular}{|l|c|c|c|}
\hline \multicolumn{1}{|c|}{ Variables } & Mean & SD & (\%) \\
\hline Successful management of heritage sites helps attract tourist groups. & 4.30 & 0.66 & 98.0 \\
\hline The infrastructure is equipped to the attract of tourism groups. & 2.13 & 0.92 & 27.3 \\
\hline $\begin{array}{l}\text { cultural heritage asset needs to be taken care of for future } \\
\text { generation. }\end{array}$ & 4.27 & 0.65 & 97.9 \\
\hline Is it possible to maintain heritage assets with recent procedures? & 2.35 & 1.09 & 36.7 \\
\hline $\begin{array}{l}\text { It is required to emphasize more on the significant issues than } \\
\text { losses. }\end{array}$ & 2.68 & 1.02 & 50.5 \\
\hline $\begin{array}{l}\text { Official procedure of interacting exist for debating heritage } \\
\text { activities. }\end{array}$ & 3.98 & 0.92 & 73.4 \\
\hline $\begin{array}{l}\text { The presence of cadres qualified for tourist guides in cultural } \\
\text { heritage sites }\end{array}$ & 4.24 & 0.76 & 95.7 \\
\hline $\begin{array}{l}\text { The important role of cultural heritage sites in local economic } \\
\text { development }\end{array}$ & 4.34 & 0.66 & 98.0 \\
\hline
\end{tabular}

Legend: Low $=1.00$ to 2.99; Moderate $=3.00$ to 3.99 and High $=4.00$ to 5.00

Constraints for managers opinions in CHS conservation and management was examined. Table 4 deals with elaboration statistics relating general issues in the CHS. On the other hand, Table 5 emphasizes on the outputs of thoughts of managers for fundamental constraints about heritage conservation.

Table 4. Choices of the managers on the fundamental affairs about the Syrian cultural heritage sites

\begin{tabular}{|l|c|c|c|c|}
\hline \multirow{2}{*}{\multicolumn{1}{c|}{ Variable }} & \multicolumn{2}{c|}{ Most Important } & \multicolumn{2}{c|}{ Second Important } \\
\cline { 2 - 5 } & $\mathbf{( N )}$ & $\mathbf{( \% )}$ & $\mathbf{( N )}$ & $\mathbf{( \% )}$ \\
\hline Reconstruction of cultural heritage sites & 14 & 73.7 & 1 & 5.3 \\
\hline Managing the use of land and buildings & 0 & 0 & 1 & 5.3 \\
\hline Creating a shield for cultural heritage & 0 & 0 & 11 & 57.8 \\
\hline Enhancing public realm & 0 & 0 & 2 & 10.5 \\
\hline Managing circulation and access & 0 & 0 & 2 & 10.5 \\
\hline Improving urban infrastructure & 5 & 26.3 & 1 & 5.3 \\
\hline Development of rural areas & 0 & 0 & 1 & 5.3 \\
\hline Other, please define & 0 & 0 & 0 & 0 \\
\hline Sum & 19 & 100.0 & 19 & 100.0 \\
\hline
\end{tabular}


Table 5. Choices of the managers on the distinct issues in CHM

\begin{tabular}{|l|c|c|c|c|}
\hline \multirow{2}{*}{ Variable } & \multicolumn{2}{c|}{ 1st Priority } & \multicolumn{2}{c|}{ 2nd Priority } \\
\cline { 2 - 5 } & $\mathbf{( N )}$ & $\mathbf{( \% )}$ & $\mathbf{( N )}$ & $(\mathbf{\%})$ \\
\hline $\begin{array}{l}\text { Noninvolvement of local community in management } \\
\text { plan }\end{array}$ & $\mathbf{9}$ & $\mathbf{4 7 . 3}$ & 2 & 10.5 \\
\hline Inappropriate management process & 2 & 10.5 & 1 & 5.3 \\
\hline Migration and demographic trends & 0 & 0 & 1 & 5.3 \\
\hline The lack of experts in field of heritage management & 3 & 15.7 & $\mathbf{5}$ & $\mathbf{2 6 . 3}$ \\
\hline Lack of funding resources & 1 & 5.3 & 4 & 21.0 \\
\hline Excessive tourism and development pressure & 1 & 5.3 & 1 & 5.3 \\
\hline Lack of public awareness and support & 1 & 5.3 & 2 & 10.5 \\
\hline Environmental and building degradation & 1 & 5.3 & 1 & 5.3 \\
\hline The country's instability because of the war & 1 & 5.3 & 2 & 10.5 \\
\hline Other, please define & 0 & 0 & 0 & 0 \\
\hline Sum & 19 & 100.0 & 19 & 100.0 \\
\hline
\end{tabular}

\section{Discussion of research result}

Public funds are main sources of finance for heritage projects. Nevertheless, reorganization is important for $\mathrm{CH}$ projects, non-scarcity in the local financial capitals is not adequate and projects have more favorable results when auxiliary options for participation are triggered. $98 \%$ of locals has no issued with the success in the management of CHS. $97.9 \%$ of locals are happy to wisely us the $\mathrm{CH}$ assets recently for future generation. $95.7 \%$ are eligible for tourist navigation. $27.3 \%$ has no issues with the infrastructure that is engineered for charming tourist groups as mentioned in Table 3. Interestingly, $36.7 \%$ are good with the heritage assets. Moreover, $73.7 \%$ considered the fundamental topic to be worked out in Syria was on the renovation of CHS as mentioned in Table 4. Unlikely, $57.8 \%$ mentioned that rebelling the enrichment of $\mathrm{CH}$ was the second priority in the Syrian $\mathrm{CH}$ as mentioned in Table 4.

Table 6. Connection within Score A1, Score A2, Score A3, Score A4, and Score A5 towards thehighest management of the socio-economic development of the Syrian territory with the objects of cultural heritage (Citizens)

\begin{tabular}{|c|c|c|c|c|c|}
\hline \multirow{4}{*}{\begin{tabular}{l}
\multicolumn{1}{c}{ Model } \\
(Constant) \\
(Score A1) attitude on \\
the situation of cultural \\
heritage sites
\end{tabular}} & \multicolumn{2}{|c|}{ Unstandardized Coefficients } & \multirow{2}{*}{$\begin{array}{c}\begin{array}{c}\text { Standardized } \\
\text { Coefficients }\end{array} \\
\text { Beta }\end{array}$} & \multirow[b]{2}{*}{$\mathrm{t}$} & \multirow[b]{2}{*}{ Sig. } \\
\hline & B & Std. Error & & & \\
\hline & -63.62 & 61.92 & & -1.221 & .222 \\
\hline & 33.45 & 17.70 & .117 & 2.163 & .020 \\
\hline \multirow{2}{*}{$\begin{array}{l}\text { (Score A4) socio- } \\
\text { economic management } \\
\text { of the Syrian cultural } \\
\text { heritage sites }\end{array}$} & -54.32 & 58.82 & & -1.209 & .212 \\
\hline & 31.25 & & .123 & 2.154 & .030 \\
\hline
\end{tabular}


Table 7. Connection within Score A1, Score A2, Score A3, Score A4, and Score A5 towards the highest management of the socio-economic development (Excluded Variables)

\begin{tabular}{|l|c|c|c|c|c|}
\hline \multicolumn{1}{|c|}{ Model } & $\begin{array}{c}\text { Beta } \\
\mathbf{I n}\end{array}$ & $\mathbf{t}$ & Sig. & $\begin{array}{c}\text { Partial } \\
\text { Correlation }\end{array}$ & $\begin{array}{c}\text { Collinearity } \\
\text { Statistics } \\
\text { Tolerance }\end{array}$ \\
\hline $\begin{array}{l}\text { (Score A2) Point of views in } \\
\text { cultural tourism and the welfare } \\
\text { towards Conservation of Syrian } \\
\text { CHS }\end{array}$ & .012 & .212 & .824 & .011 & .809 \\
\hline $\begin{array}{l}\text { (Score A3) The significance of } \\
\text { keeping unused values of CH in } \\
\text { Syria }\end{array}$ & -.019 & -.294 & .771 & -.015 & .925 \\
\hline $\begin{array}{l}\text { (Score A5) Attitude towards the } \\
\text { involvement of local community } \\
\text { in Syrian cultural heritage sites } \\
\text { management }\end{array}$ & .034 & .637 & .523 & .036 & .908 \\
\hline
\end{tabular}

From the analysis Table 6 and Table 7), the study found that the variable the situation of cultural heritage sites and the variable of socio- economic management of the Syrian cultural heritage sites have had the most impact on the highest management of the socioeconomic development of the Syrian territory with the objects of $\mathrm{CH}$ differentiated with an important value of $\mathrm{P}=0.02,0.03$, which gave a solution to be under than $\alpha=0.05$. Moreover, solutions triggered Score A2, Score A3 and Score A5 not impacted the management of the socio-economic development of the Syrian territory with CHS as the value of $\mathrm{P}>\alpha=0.05$.

Table 8 shows result in impacts of the socio-economic circumstances of the group for management with a motive of developing Syrian territory for CHS. Research shows, management for the development with the objects of $\mathrm{CH}$ to be optimistically correlated with the gender, income, education and occupation of the inhabitants. Although, it had an negative connection with other constraints.

Table 8 Power of the socio-economic circumstances of regional group the management of the socioeconomic development of the Syrian territory with the objects of cultural heritage

\begin{tabular}{|l|c|c|}
\hline \multirow{2}{*}{ Variable } & \multicolumn{2}{|c|}{$\begin{array}{c}\text { Management of the socio-economic development of the Syrian } \\
\text { territory with the objects of cultural heritage }\end{array}$} \\
\cline { 2 - 3 } & t-stat. & p-value \\
\hline Gender & $\mathbf{2 . 5 6 4}$ & $\mathbf{0 . 0 0 5}$ \\
\hline \multirow{2}{*}{ Variable } & $\begin{array}{c}\text { Management of the socio-economic development of the Syrian } \\
\text { territory with the objects of cultural heritage }\end{array}$ \\
\cline { 2 - 3 } & F-stat & p-value \\
\hline Age & 1.334 & 0.282 \\
\hline Race & 0.873 & 0.423 \\
\hline Religion & 1.965 & 0.087 \\
\hline Education & $\mathbf{2 . 4 2 5}$ & $\mathbf{0 . 0 0 6}$ \\
\hline Family members & 0.407 & 0.666 \\
\hline Earning & $\mathbf{3 . 0 0 5}$ & $\mathbf{0 . 0 0 3}$ \\
\hline Occupation & $\mathbf{2 . 8 0 7}$ & $\mathbf{0 . 0 0 4}$ \\
\hline
\end{tabular}


Table 9. Impact of the socio-economic circumstance towards point of view of regional inhabitants

\begin{tabular}{|c|c|c|c|c|c|c|c|c|c|c|}
\hline \multirow{3}{*}{\begin{tabular}{c|} 
Variable \\
Gender
\end{tabular}} & \multicolumn{2}{|c|}{$\begin{array}{l}\text { Circumstances } \\
\text { on the situation } \\
\text { of CH sites (A1) }\end{array}$} & \multicolumn{2}{|c|}{$\begin{array}{c}\text { Circumstance } \\
\text { towards cultural } \\
\text { tourism and its } \\
\text { benefits for the } \\
\text { conservation (A2) }\end{array}$} & \multicolumn{2}{|c|}{$\begin{array}{l}\text { Significance of } \\
\text { preserving the } \\
\text { unused values of } \\
\text { the } \mathrm{CH}(\mathrm{A3})\end{array}$} & \multicolumn{2}{|c|}{$\begin{array}{c}\text { Socio- economic } \\
\text { management of } \\
\text { the Syrian CH } \\
\text { (A4) }\end{array}$} & \multicolumn{2}{|c|}{$\begin{array}{c}\text { Point of view } \\
\text { towards the } \\
\text { involvement of } \\
\text { regional } \\
\text { inhabitants in } \\
\text { CHS (A5) }\end{array}$} \\
\hline & t-stat. & $p$-value & $t$-stat. & $p$-value & $t$-stat. & $p$-value & $t$-stat. & $p$-value & $t$-stat. & $p$-value \\
\hline & -1.853 & 0.045 & 0.435 & 0652 & 1.651 & 0.099 & -1.307 & 0.196 & 0.562 & 0.186 \\
\hline \multirow{2}{*}{ Variable } & \multicolumn{2}{|c|}{ A1 } & \multicolumn{2}{|c|}{ A2 } & \multicolumn{2}{|c|}{$\mathbf{A 3}$} & \multicolumn{2}{|c|}{ A4 } & \multicolumn{2}{|c|}{ A5 } \\
\hline & $F$-stat. & $p$-value & F-stat. & $p$-value & $F$-stat. & $p$-value & $F$-stat. & $p$-value & $F$-stat. & p-value \\
\hline 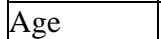 & 1.797 & & & & 2.1 & & 1.293 & 0.267 & 1.294 & \\
\hline ace & & & & & & & & & 1.2 & 0.308 \\
\hline Relis & & & & & & & & & & 29 \\
\hline Education & & & & & & & & & & \\
\hline $\begin{array}{l}\text { Family } \\
\text { members }\end{array}$ & 0.493 & 0.618 & 1.004 & 56 & 0.117 & 0.889 & 0.634 & .532 & 0.491 & .614 \\
\hline Zarning & & & & & & & & & 1.558 & \\
\hline ccupation & 1.524 & 0.004 & 1.284 & 0.279 & 0.954 & 0.445 & 1.807 & 0.149 & 1.608 & 0.157 \\
\hline
\end{tabular}

Table 9 shows the outcome of the inhabitants. Experimental study concludes that the socio-economic circumstances did not affected behavior in the cultural tourism and its gains for conservation, freezing unusable values of the $\mathrm{CH}$ and simultaneously interference in CHS. Moreover, the gender, income and occupation of the inhabitants were found to have impact on behavior in situation of CHS. Additionally, religion and education of the local interest group affected their concept on socio-economic management of the Syrian $\mathrm{CH}$ unlike with other constraints. The research ensures a strong connection within cultural heritage and socio- economic development. Auxiliary, the economic constraints of $\mathrm{CH}$ has two methods: i) Used values refers to the goods and services that can be exchanged with monetary value in existing markets. ii) Unused values refers to economic values which are not exchangeable or controlled by markets. Therefore, inhabitants are not able to allocate resources for protection. In Syria, heritage management plan (HMP) is necessary for the conservation of HS. So, HMP is for managing a particular HS or development needs construction of all important issues. Importance for creating a shield and conserve HS, as well as the importance to input new techniques in them by constructing all important data, understanding and operation that triggers development its system.

\section{Conclusion}

In conclusion, Syria is generally lacking with regards to the sustainable methods in measuring the $\mathrm{CH}$ assets. $\mathrm{CH}$ conservation from an economic point of view triggered a new method for HS planning and management in Syria. The economic numeric figures are the most effective methods for community to examine and decide on the relative importance of the $\mathrm{CH}$ conservation. It will be in bad condition and consequently conservation will trigger unsustainable between the social rules unless the non-technical difficulties of the $\mathrm{CH}$ preservation, it acts in modern society, and the social, economic and political through which conservation works are better concluded and forwarded to stakeholders. Necessities to examine how this HS is apportioned and taken care of, all of 
which have impacted people's well-being, behaviors and involvement for $\mathrm{CH}$ conservation. Examined values for heritage is said to have a very important activity in any conservation effort since numerical figures strongly influence the decisions that are made by the society. Interference of locals in measuring the $\mathrm{CH}$ can be considered as more important for feasibility. Creating institutional structure and enriching a given area for $\mathrm{CH}$ public authorities should keep in concept that the capacity and likelihoods of economic and non-economic impacts of heritage tourism on the local environment always positively correlated on many factors, as per locality specification (e.g., its heritage assets, population, wants, qualities and behaviors of the society) and on the category of tourism upgraded in a available region.

\section{References}

1. A. Zulfiqar, S.B. Bhaskar. Indian J. Anaesth., 60,9:662-669(2016). https://www.ncbi.nlm.nih.gov/pmc/articles/PMC5037948/

2. M.E. Berg, J.T. Karlsen. J. Work. Learn., 24,3:177-199(2012). https://www.emeraldinsight.com/doi/abs/10.1108/13665621211209267

3. C. Tweed, M. Sutherland. Landsc. Urban Plan. 83,1:62-69(2007). https://www.sciencedirect.com/science/article/pii/S0169204607001442

4. K.M. Murzyn. Economic and Environmental Studies., 12,2:113-133(2012). https://www.econstor.eu/handle/10419/93213

5. J. Gascón. J. Sustain. Tour., 21,5:1-16(2012). https://www.tandfonline.com/doi/abs/10.1080/09669582.2012.721786

6. W. Gamini, J. Thompson, C. Young, Managing Cultural World Heritage. Paris, France: UNESCO, (2013). pp. 152. https://whc.unesco.org/document/125839

7. A.K. Fenda. J. Clean. Prod., 84:773-782(2014). https://www.sciencedirect.com/science/article/pii/S0959652614000031

8. T.H. Tuan, S. Navrud. J. Cult. Herit., 9:326-337(2008). https://www.sciencedirect.com/science/article/pii/S1296207408000459

9. N. Beaumont, D. Dredge. J. Sustain. Tour., 18,1:7-28(2009). https://www.tandfonline.com/doi/abs/10.1080/09669580903215139

10. S. Poudel, G.P. Nyaupane, M. Budruk. J. Travel Res., 55,4:465-480(2014). https://journals.sagepub.com/doi/abs/10.1177/0047287514563166

11. UNESCO. Creative Economy Report 2013: Widening Local Development Pathways. New York and Paris: UNDP/UNESCO, (2013). p.12. http://www.unesco.org/culture/pdf/creative-economy-report-2013.pdf

12. H. Mair, D.G. Reid. Leisure/Loisir, 31,2:403-425(2007). https://www.tandfonline.com/doi/abs/10.1080/14927713.2007.9651389

13. T. Jamal, A. Stronza. J. Sustain. Tour., 17,2:169-189(2009). https://www.tandfonline.com/doi/abs/10.1080/09669580802495741

14. D.S. Yates, D.S. Moore, D.S. Starnes, The Practice of Statistics, 3rd ed., USA: Slander (2008). p. 35. https://www.slader.com/textbook/9781429281898-thepractice-of-statistics-3rd-edition/

15. M. Wray, D. Dredge, C. Cox, J. Buultjens, M. Hollick, D. Lee, et. al., Sustainable Tourism Regional Tourism Destination: Best Practice For Management, Development And Marketing. Australia: Sustainable Tourism (SRC) (2010). p.181. https://pdfs.semanticscholar.org/bbfa/b68fdcb2b9b0933c5222c158e4ef93bc1857.pdf

16. S. Karen, R. Frances, P. Venda. J. Rural Stud., 59:173-182(2018). https://www.sciencedirect.com/science/article/pii/S0743016716301176 
17. M.A. Vecco. J. Cult. Herit., 11:321-324(2010). http://orcp.hustoj.com/wpcontent/uploads/2016/01/2010-A-definition-of-cultural-heritage_From-the-tangibleto-the-intangible.pdf

18. E. Okazak. J. Sustain. Tour., 16,5:511-529(2008). https://www.tandfonline.com/doi/abs/10.1080/09669580802159594

19. N.A. David, L.E. Xiaoli, Tour. Manag., 70:333-340(2019). https://www.sciencedirect.com/science/article/pii/S0261517718302127

20. L. Bernard. Tour. Manag. Perspect., 25:161-164(2018). https://www.cabdirect.org/cabdirect/abstract/20183196398

21. B. Darko. Procedia-Social Behav. Sci., 188:27-34(2015). https://www.sciencedirect.com/science/article/pii/S187704281502128X

22. D.C. Comer, Tourism and Archaeological Heritage: Management at Petra, Driver to Development? New York: Springer (2012). p. 187.

https://link.springer.com/content/pdf/10.1007/978-1-4614-1481-0.pdf

23. I. Fitri, Y. Ahmad, F. Ahmad. Procedia-Social Behav. Sci., 184:71-78(2015). https://www.sciencedirect.com/science/article/pii/S1877042815032978

24. P.C. Guzmán, R. Pereira, A.R. Colenbrander. Cities, 60(Part A):192-201(2017). https://www.sciencedirect.com/science/article/pii/S026427511630539X

25. S. Karen, R. Frances, P. Venda. Jour. R. S., 59:173-182(2018). https://www.sciencedirect.com/science/article/pii/S0743016716301176 